\title{
A CONVENÇÃO SOBRE IMUNIDADE DO ESTADO E SEUS BENS E O DIREITO BRASILEIRO
}

\author{
André Lipp Pinto Basto Lupi ${ }^{1}$
}

\begin{abstract}
RESUMO
A imunidade de jurisdição consiste no impedimento para que um Estado exerça sua jurisdição sobre pessoa jurídica de Direito Internacional Público em seus próprios tribunais. Contudo, essa proteção, que já foi absoluta, relativizou-se. Admite-se hoje em todo o mundo que certos atos não são imunes aos tribunais locais. Essa flexibilização não tem, porém, contornos muito precisos. Cada juiz esforça-se por perceber os movimentos gerais da prática dos Estados e assim determinar o conteúdo dessa regra do costume internacional. O objetivo deste artigo é, portanto, o de verificar como o judiciário brasileiro vem interpretando a imunidade de jurisdição dos Estados estrangeiros para contrastar as normas oriundas da jurisprudência nacional com a Convenção das Nações Unidas sobre Imunidade de Jurisdição do Estado e de seus Bens, aprovada em 2004. A intenção é avaliar se a incorporação desta Convenção trará impactos significativos sobre o estado atual do direito brasileiro. Para isso, o artigo, que se valeu de técnicas de pesquisa a documental e a bibliográfica, expõe sinteticamente as normas da Convenção, depois refere a jurisprudência brasileira nos principais tópicos atinentes às exceções à imunidade, para, ao final, apresentar um balanço conclusivo sobre divergências e convergências entre os modelos brasileiros e a Convenção internacional.
\end{abstract}

Palavras-chave: Imunidade de Jurisdição; Convenção das Nações Unidas sobre Imunidade de Jurisdição; Jurisprudência brasileira.

State immunity is the right one State has to avoid being judged by the Courts of another States. However important, this protection to the subjects of International Law has turned to a more restrictive approach. Throughout the world it is assumed that certain acts cannot be immune to local Courts. This relativization does not have precise borders. Each judge must find in State practice the contents of this international customary rule. Hence, this article aims to analyze how Brazilian Judicial Power is

\footnotetext{
${ }^{1}$ Professor do Programa de Mestrado e Doutorado em Direito da Universidade do Vale do Itajaí. Doutor em Direito pela Universidade de São Paulo (lupi@univali.br). Este trabalho constitui um relato de pesquisa desenvolvida com apoio do CNPq, no programa PIBIC, e deve ser lido como um work-inprogress. Versão anterior foi apresentada no CONPEDI realizado em Florianópolis no segundo semestre do ano de 2010.
} 
facing State immunity rules, so to then compare national jurisprudence and the United Nations Convention on State Immunity and their Property, approved in 2004. The idea is to evaluate which impacts the incorporation of that Convention will have on current Brazilian Law. To expose the results of this research, we present the main rules of the Convention, and then go into detail into different topics relating to exceptions of immunity. In the end we conclude posing convergent and divergent patterns between national jurisprudence and the UN Convention. The article was produced by documental and bibliographical research.

Keywords: State Immunity; United Nations Convention on State Immunity and their Property; Brazilian Jurisprudence.

\section{Introdução}

Pode o Estado estrangeiro ser processado ante os tribunais nacionais? A resposta variou no passar dos anos. No direito brasileiro, a imunidade do Estado foi considerada absoluta até poucas décadas atrás. Relativizou-se, posteriormente, admitindo o processamento em certos casos.

Assim, a resposta à pergunta inicial, hoje certamente afirmativa, vem seguida de condições; um Estado estrangeiro somente de forma excepcional pode ver relegados seus direitos soberanos e ser submetido ao poder jurisdicional de uma autoridade parelha (outro Estado).

As hipóteses em que o direito brasileiro admite processar e julgar um Estado estrangeiro não são delimitadas pela lei nacional, nem por tratado, pois derivam do costume. No âmbito internacional, a imunidade de jurisdição dos Estados foi objeto de um processo de codificação no âmbito da Organização das Nações Unidas. Essa codificação resultou numa Convenção, à qual o Brasil ainda não aderiu. Questiona-se neste trabalho, portanto, qual seria o impacto desta adesão para o direito brasileiro.

A imunidade está baseada no princípio da igualdade jurídica dos Estados, segundo o qual entre pares não há subordinação (par in parem non habet imperium). Sendo o Direito Internacional visto classicamente como um direito de coordenação, regulando a interação entre Estados soberanos, que não se subordinam a poderes da mesma natureza, nada mais lógico do que impedir que um exerça seus poderes sobre o outro, seja por seus braços executivo, legislativo ou, como é o caso, pelo judiciário. 
Um corolário da imunidade também demonstra sua utilidade prática, pois permitir que um Estado processasse aos demais em seus próprios tribunais acarretaria não só ofensas à soberania na sua acepção mais cara aos ufanismos nacionalistas, como imporia aos Estados a necessidade de possuir procuradores constituídos para representálos em todos os demais territórios, já que qualquer particular poderia acioná-los.

Todavia, com o advento do Estado do bem estar social, do Estado empresário e do Estado socialista, entregues a funções antes reservadas à esfera privada, a regra da imunidade necessitou ser flexibilizada. ${ }^{2} \mathrm{O}$ processo de moldagem das diversas exceções que acomodavam as novas situações foi iniciado na década de 1970. O marco mais citado é a Tate Letter, instrução do Departamento de Estado dos EUA às cortes do país para que relativizassem a imunidade concedida a Estados estrangeiros em certos casos. ${ }^{3}$ Depois adveio a Convenção Europeia, e a ela secundaram as leis americana e inglesa, seguidas por um outro conjunto de leis nacionais, dentre as quais destacam-se a australiana e a canadense. ${ }^{4}$

Como dito, no Brasil o tema foi regulado exclusivamente pelo costume. Daí a dificuldade dos tribunais nacionais em acompanhar a prática e a opinio juris internacional para manter-se atualizados sobre o teor das regras de imunidade, problema apontado com precisão por Saliba. ${ }^{5}$

A jurisprudência pátria mudará radicalmente nos anos 1980. Da imunidade absoluta declarada num famoso precedente em que Síria e Egito litigavam por um imóvel no Rio de Janeiro ${ }^{6}$, chegar-se-á à afirmação da imunidade relativa para conceder

\footnotetext{
2 Cf. SOARES, Guido. Órgãos dos Estados nas relações internacionais: formas da diplomacia $e$ imunidades. Rio de Janeiro: Forense, 2001. p. 182.

3 UNITED STATES. Department of State. Tate Letter. 19.05.1952. Disponível na internet: <http://www.law.berkeley.edu/faculty/ddcaron>. Acesso em 24 de setembro de 2006.

${ }^{4}$ CANADA. Act to Provide for Immunity in Canadian Courts. International Legal Materials, v. 21, p. 798-801, 1982; UNITED STATES OF AMERICA. Foreign Immunities Act. International Legal Materials, v. 15, p. 1388-1392, 1976; UNITED KINGDOM. State Immunity Act. International Legal Materials, v. 17, p. 1123-1129, 1978.

5 SALIBA, Aziz Tuffi. A imunidade absoluta de jurisdição de Estados: "sólida regra costumeira" ou mito? Revista Brasileira de Direito Público, Belo Horizonte, v. n. 8, p. 23-33, 2005.

${ }^{6}$ SUPREMO TRIBUNAL FEDERAL. Ação Cível Originária n. 298, do Distrito Federal. Tribunal Pleno. Relator Min. Soares Munoz. Julgamento de 14 de abril de 1982. DJ, 17.12.1982. p. 13201. Doravante as decisões do Supremo Tribunal Federal, do Superior Tribunal de Justiça e do Tribunal Superior do Trabalho serão referidas fazendo uso das siglas STF, STJ e TST. Um outro precedente demonstrativo da prática da imunidade absoluta encontra-se no parecer de VALLADÃO, Haroldo. O Ministério das Relações Exteriores deve continuar a manter entendimentos com o Poder Judiciário... (16.12.1963) In:
} 
o direito de Genny de Oliveira prosseguir no reclamo dos direitos trabalhistas de seu falecido marido, empregado da República Democrática Alemã no Brasil. ${ }^{7}$

A matéria foi codificada em 2004 pela Convenção das Nações Unidas sobre Imunidade de Jurisdição dos Estados Estrangeiros e seus Bens ${ }^{8}$ (doravante "Convenção"), ainda não firmada pelo Brasil, cumpre indagar: qual será o impacto da ratificação e promulgação da Convenção sobre a jurisprudência brasileira relativa à imunidade de jurisdição? O objetivo, pois, é o de determinar que mudanças no regime jurídico hoje aplicado aos Estados estrangeiros e seus bens no país deverão ocorrer em virtude da adesão do Brasil à Convenção. As questões processuais não serão abordadas no artigo, ficando relegado a outro estudo o exame dos procedimentos de admissão da causa, citação, renúncia, embargos em caso de execução e outros temas deste jaez.

Para tanto, num tópico seguinte serão expostas as regras da Convenção. Posteriormente abordar-se-á a jurisprudência brasileira, focalizando as exceções à regra da imunidade trazidas pela Convenção. Um balanço final consta ao final do artigo para responder de forma objetiva ao problema posto.

\section{As regras da Convenção}

A Convenção em estudo é fruto do processo de codificação, levado a cabo no seio das Nações Unidas, para dar cumprimento a norma expressa da Carta da ONU, contida no artigo 13.1.a:

Artigo 13.1. A Assembléia Geral iniciará estudos e fará recomendações, destinados a: a) promover cooperação internacional no terreno político e incentivar o desenvolvimento progressivo do direito internacional e a sua codificação;

MEDEIROS, Antonio Paulo Cachapuz (org.). Pareceres dos Consultores Jurídicos do Itamaraty. Volume VI (1961-1971). Brasília: Senado Federal, 2002, p. 118.

${ }^{7}$ STF. Apelação Cível n. 9696. de São Paulo. Tribunal Pleno. Relator Min. Sydney Sanches. Julgamento de 31 de maio de 1989. DJ, 12.10.1990. p. 11045.

${ }^{8}$ United Nations Convention on Jurisdictional Immunities of States and Their Property. Adopted by the General Assembly of the United Nations on 2 December 2004. Official Records of the General Assembly, Fifty-ninth Session, Supplement No. 49 (A/59/49). Disponível na internet: <http://untreaty.un.org/ilc/texts/instruments/english/conventions/4_1_2004.pdf >. Acesso em 28.08.10. 
O trabalho de codificação segue, portanto, diretrizes da Assembléia Geral das Nações Unidas e obedece o fluxo previsto no Estatuto da Comissão de Direito Internacional, órgão encarregado dos estudos encomendados pelo órgão político maior das Nações Unidas. ${ }^{9}$ A intenção da conversão de regras costumeiras em tratados é a de encontrar maior segurança no estabelecimento de textos convencionais. Nada obstante, estes se baseiam no costume e esforçam-se por respaldar as opiniões dos Estados. Tanto assim é que o processo não prescinde de numerosas manifestações dos Estados (artigo 16 do Estatuto da CDI). Para dizer de modo metafórico, a CDI alimenta-se da prática estatal informada pelos próprios Estados para elaborar o tex to que codificará o costume formado por tal prática. Além disso, mantém um constante diálogo com os Estados sobre o andamento dos Projetos de Artigos (Draft Articles). A lógica de tamanha deferência veste-se de evidente intenção de colher a adesão dos Estados aos Projetos, sob pena de estes nunca atingirem o fim a que se propuseram, já que sua conversão em tratados vigentes depende sempre da participação de um número significativo de Estados que os adotem.

A Convenção foi adotada pela Assembleia Geral em 2004. Obteve até o momento 29 assinaturas e apenas onze ratificações. ${ }^{10}$ Necessita de trinta ratificações para entrar em vigor (artigo 30).

O Prêambulo da Convenção contém assunções importantes relativamente à fonte costumeira da imunidade e do papel suplementar que o costume continuará a desempenhar mesmo depois da entrada em vigor da Convenção. Reconhece, outrossim, a evolução das posições dos Estados nessa matéria, que leva à codificação com o intuito de "harmonizar" as práticas nesse domínio.

A Convenção não se aplica à imunidade de embaixadas e consulados, nem aos seus respectivos bens e funcionários, tampouco a chefes de Estado. Excluídos do seu escopo estão também aviões e objetos espaciais.

Após a seção de definições e delimitações de sua aplicabilidade, a Convenção dedica-se ao mérito da questão, a partir do artigo $5^{\circ}$. Este dispositivo consigna de forma

\footnotetext{
9 ORGANIZAÇÃO DAS NAÇÕES UNIDAS. Estatuto da Comissão de Direito Internacional. In: MELLO, Rubens Ferreira de. Textos de Direito Internacional e de História Diplomática. Rio de Janeiro: Coelho Branco F ${ }^{\circ}$, 1950. p. 781-797.

${ }^{10}$ UNITED NATIONS. Status of Multilateral Treaties Deposited with the Secretary General. Disponível em: < http://treaties.un.org/>. Acesso em 18.05.2011.
} 
límpida que o princípio geral segue sendo a concessão de imunidade pelos tribunais de um Estado aos órgãos e bens de outro Estado:

Artigo 5 - Imunidade de Estado. Um Estado goza de imunidade, respectivamente a si próprio e à sua propriedade, perante a jurisdição dos tribunais de outro Estado, ressalvadas as disposições da presente Convenção. ${ }^{11}$

A imunidade deve ser declarada de ofício, segundo dispõe o artigo $6^{\circ}$. Um Estado pode, contudo, renunciar à sua imunidade, seja por contrato escrito, por tratado ou por manifestação perante o tribunal em que tramita o processo $\left(\operatorname{artigo} 7^{\circ}\right.$ ). Vindo ante o juízo como autor ou em contestação ao mérito da causa, o Estado terá renunciado tacitamente à sua imunidade (artigo $\left.8^{\circ}\right)$.

No que toca as exclusões, tema que mais interessa a este trabalho, a Convenção arrola as transações comerciais (artigo 10), as relações de trabalho com pessoas não nacionais do Estado empregador ou residentes no Estado do local da prestação dos serviços (artigo 11), os danos decorrentes de lesão ou morte ou à propriedade estrangeira, tangível ou intelectual (artigos 12 e 14), disputas sobre imóveis ou sobre bens envolvidos em procedimento sucessório, vacância ou doação (artigo 13), questões relativas a empresas nas quais o Estado tenha participação (artigo 15), a navios usados para fins não-governamentais (artigo 16) e, finalmente, as cláusulas arbitrais e compromissos arbitrais a que o Estado tenha se aderido (artigo 17). Em todas essas situações, o princípio geral estabelecido no artigo $5^{\circ}$ não será aplicado. Particulares e o Estado local poderão exercer sua jurisdição sobre bens e sobre o próprio Estado estrangeiro quando se estiver diante de uma das hipóteses do longo rol descrito neste parágrafo.

\section{A jurisprudência}

\subsection{Litígios trabalhistas}

\footnotetext{
${ }^{11}$ Doc. cit. No original: “Article 5. State immunity. A State enjoys immunity, in respect of itself and its property, from the jurisdiction of the courts of another State subject to the provisions of the present Convention."
} 
O princípio da imunidade de jurisdição, como já dito na introdução deste trabalho, encontra-se bem sedimentado na jurisprudência e na prática diplomática brasileira. Prova-o extensa lista de julgados dos tribunais superiores. ${ }^{12}$ A manutenção da imunidade somente é reconhecida quando amparada por tratado, situação que ocorre com frequência com organizações internacionais, mas não com Estados.

A invocação de imunidade absoluta no processo de conhecimento juslaboral é, portanto, rara, até mesmo desconhecida nos últimos anos, o mesmo não ocorrendo com imunidade dos bens à execução, que segue incólume ${ }^{13}$.

O paradigma da mudança, antes apontado, foi o caso Genny de Oliveira. Nele o Ministro Rezek, que depois seria nomeado juiz da Corte Internacional de Justiça, pronunciou-se nos seguintes termos:

não podemos mais, neste Plenário, dizer que há uma sólida regra de direito internacional costumeiro, a partir do momento em que desertam dessa regra os Estados Unidos da América, a Grã-Bretanha e tantos outros países do hemisfério norte. ${ }^{14}$

O campo no qual no Brasil inaugurou-se a fenda na muralha da imunidade foi então o trabalhista. É também aquele há mais solidez na posição dos tribunais. Não há imunidade para o Estado que contrata brasileiros ou estrangeiros residentes no País. Alguns outros princípios auxiliam essa interpretação, dentre eles o contido no artigo 114

\footnotetext{
${ }^{12}$ No STJ: Recurso Ordinário $N^{o} 26$, Relator Ministro Vasco Della Giustina, julgado em 20/05/2010, DJe 07/06/2010, Recurso Ordinário $N^{o} 78$, Relator Ministro João Otávio de Noronha, julgado em 18/08/2009, DJe 08/09/2009, Recurso Ordinário $N^{\circ} 72$, Relator João Otávio de Noronha, julgado em 18/08/2009, DJe 08/09/2009, Recurso Ordinário $N^{o} 57$, Relatora Ministra Nancy Andrighi, Relator p/ acórdão Ministro Aldir Passarinho Junior, voto-vista do Ministro Sidnei Benetti, julgado em 21/08/2008, DJe 14/09/2009, Recurso Ordinário $N^{o}$ 69, Relator Ministro João Otávio de Noronha, julgado em 10/06/2008, DJe 23/06/2008, Recurso Especial $N^{o} 436.711$, Relator Ministro Humberto Gomes de Barros, julgado em 25/04/2006 DJ 22/05/2006, Recurso Ordinário N ${ }^{o} 39$, Relator Ministro Jorge Scartezzini, julgado em 06/10/2005, DJ 06/03/2006, Recurso Ordinário $N^{\circ} 6$, Relator Ministro Garcia Vieira, julgado em 23/03/1999, DJ 10/05/1999, Recurso Ordinário $N^{o}$ 57, Relatora Ministra Nancy Andrighi, Relator p/ acórdão Ministro Aldir Passarinho Junior, julgado em 21/08/2008, DJe 14/09/2009, Recurso Ordinário $N^{o}$ 33, Relatora Ministra Nancy Andrighi, julgado em 02/06/2005, DJ 20/06/2005, Recurso Ordinário $N^{o} 23$, Relator Aldir Passarinho Junior, julgado em 28/10/2003, DJ 19/10/2003, Recurso Ordinário N ${ }^{o}$, Relator Ministro Cláudio Santos, julgado em 08/08/1995, DJ 11/09/1995, Apelação Cível No 9, Relator Ministro Dias Trindade, julgado em 30/09/1991, DJ 28/10/1991, Apelação Cível $N^{o} 2$, Relator Ministro Barros Monteiro, julgado em 07/08/1990, DJ 03/09/1990.

${ }^{13}$ STF. ACO 543 AgR, Relator Min. Sepúlveda Pertence, Tribunal Pleno, julgado em 30/08/2006, DJ 2411-2006, p. 61.

${ }^{14}$ STF. Apelação Cível n. 9696. de São Paulo. Tribunal Pleno. Relator Min. Sydney Sanches. Julgamento de 31de maio de 1989. DJ, 12.10.1990. p. 11045.
} 
da Constituição Federal, que expressamente inclui os Estados estrangeiros no bojo dos empregadores sujeitos à jurisdição trabalhista:

Art. 114. Compete à Justiça do Trabalho processar e julgar:

I - as ações oriundas da relação de trabalho, abrangidos os entes de direito público externo e da administração pública direta e indireta da União, dos Estados, do Distrito Federal e dos Municípios;

Também o princípio da proibição do enriquecimento sem causa foi invocado pelo Supremo Tribunal Federal:

Privilégios diplomáticos não podem ser invocados, em processos trabalhistas, para coonestar o enriquecimento sem causa de Estados estrangeiros, em inaceitável detrimento de trabalhadores residentes em território brasileiro, sob pena de essa prática consagrar censurável desvio ético-jurídico, incompatível com o princípio da boa-fé e inconciliável com os grandes postulados do direito internacional. $^{15}$

Os tribunais trabalhistas têm posição bastante firme em favor da excepcionalidade da matéria laboral. O recente acórdão abaixo transcrito contempla a síntese dessa postura:

É entendimento jurisprudencial desta Corte Especializada que a imunidade de jurisdição dos Estados estrangeiros é relativa, em relação às demandas que envolvam atos de gestão, e em que se debate o direito a parcelas decorrentes da relação de trabalho. Na hipótese, sendo a Reclamada pessoa jurídica de Direito Público Externo, Estado estrangeiro, não se há falar em imunidade de jurisdição. $^{16}$

\footnotetext{
${ }^{15}$ STF. $R E 222368$ AgR, Relator Min. Celso de Mello, Segunda Turma, julgado em 30/04/2002, DJ 1402-2003. p. 70.

16 TST. AIRR - 83140-02.2003.5.10.0008, Relator Ministro Mauricio Godinho Delgado, Data de Julgamento: 26/05/2010, 6 ${ }^{\text {a }}$ Turma, Data de Publicação: 04/06/2010.
} 
Não escapam nem mesmo as organizações internacionais, como o Programa das Nações Unidas para o Desenvolvimento - PNUD, ${ }^{17}$ - protegido não por costume, mas por acordo de sede -, nem a empresa Itaipu ${ }^{18}$. A questão da imunidade de organizações internacionais amparadas por convenção específica que prevê a manutenção da possibilidade de evitar a justiça local tem tratamento diverso no Supremo Tribunal Federal. Lá tais organismos têm obtido imunidade. ${ }^{19}$ Inclusive o PNUD obteve decisão favorável para suspender a execução determinada por tribunal do trabalho e o voto da relatora endossou a tese da imunidade com base na Convenção das Agências Especializadas das Nações Unidas. ${ }^{20}$

No Superior Tribunal de Justiça melhor sorte não tiveram os Estados que reclamaram imunidade. ${ }^{21}$ Pesquisa elaborada por Calsing indica que realmente são muitas as reclamações trabalhistas contra Estados estrangeiros e Organizações Internacionais. ${ }^{22}$ A consolidação da posição brasileira conduziu o Itamaraty a expedir Nota Circular às delegações estrangeiras explicitando as restrições à imunidade em matéria trabalhista. $^{23}$

\subsection{Imunidade de jurisdição em questões de propriedade estrangeira}

\footnotetext{
${ }^{17}$ TST. $R R$ - 1663/2002-005-23-00.8. Rel. Maria de Assis Calsing, 13/05/2009.

${ }^{18}$ TST. $R R$ - 3386/1997-658-09-00.0. Rel. Maria Cristina Irigoyen Peduzzi. 14/08/2009.

${ }^{19}$ STF. ACi 9703 / SP. Relator Min. Djaci Falcao. Tribunal Pleno. Julgamento 28/09/1988. DJ 27-101989. p.16391.

${ }^{20}$ STF. RE 578543 / MT. Relatora Min. Ellen Gracie. Ainda não julgado. Movimentação disponível em: <www.stf.jus.br>. Consulta em 28.08.10. O Min. Rezek, em conferência, sustentou a mesma posição: "Não podemos considerar as organizações internacionais como uma coisa homogênea, eu até diria, como algo onde existe igualdade qualitativa. Cada uma delas há de ser tratada em função do seu próprio estatuto e em função do estatuto jurídico exato da sua relação com o Brasil, da sua instalação no Brasil." REZEK, J. F. A imunidade das organizações internacionais no Século XXI. In: MADRUGA Filho, Antenor P.; GARCIA, Márcio. (Orgs.) A imunidade de jurisdição e o judiciário brasileiro. CEDI: Brasília, 2002. p. 17.

${ }^{21}$ STJ. RO 23/PA. Recurso Ordinario. 2002/0096286-5. Relator Ministro Aldir Passarinho Junior. Quarta Turma. 28/10/2003. DJ 19.12.2003 p. 464. STJ. RO 33/RJ. 2003/0235440-6. Relatora Ministra Nancy Andrighi. Terceira Turma. 0206/2005.

${ }^{22}$ A autora indica só no TRT da $10^{\mathrm{a}}$ Região 350 ações contra Estados e 33 contra Organizações Internacionais entre 1999 e 2001. CALSING, M.A. Distinção entre Imunidade de jurisdição de Estado estrangeiro e das organizações internacionais em matéria trabalhista. In: MADRUGA Filho, Antenor P.; GARCIA, Márcio. (Orgs.) A imunidade de jurisdição e o judiciário brasileiro. CEDI: Brasília, 2002. p. 202.

${ }^{23}$ MINISTÉRIO DAS RELAÇÕES EXTERIORES. Nota Circular n. 18/95.
} 
O Código de Processo Civil determina em seu artigo 89 que os juízes nacionais têm "competência internacional” (leia-se jurisdição) para processar e julgar litígios referentes a propriedades imóveis situadas em território nacional. Justifica-se a regra pelo método registral de transmissão e aferição da propriedade imóvel no Brasil; por ser constitutivo o registro de propriedade, estranho seria que ordens estrangeiras pudessem alterá-lo.

Apesar do dispositivo do codex antes referido, curiosamente o Supremo Tribunal Federal preferiu não julgar um litígio entre Egito e Síria surgido nos idos de 1980. A discórdia instalou-se pela ocupação pelo Egito de prédio de propriedade Síria após a dissolução da República Árabe Unida, Estado que congregou as duas nações árabes numa só entidade política. O Tribunal, liderado pelo voto de Clóvis Ramalhete, entendeu que ofendia a soberania egípcia dar andamento ao feito, além de considerar inapropriado o Brasil julgar litígios entre dois Estados, controvérsia de competência típica da Corte Internacional de Justiça. ${ }^{24}$

\subsection{Responsabilidade civil}

Não é pacífica a jurisprudência nacional relativa à imunidade do Estado estrangeiro em casos de responsabilidade civil. A casuística demonstrará uma oscilação nos critérios, que pode apenas em parte ser explicada com base em questões cronológicas.

Há registro de diversas decisões concedendo imunidade em casos desse gênero. Num caso de acidente de veículos, por exemplo, o STF extinguiu a ação contra o Consulado, proprietário do carro, mas admitiu o prosseguimento contra o motorista, o Cônsul da Polônia, com fulcro no artigo 41.3.b da Convenção de Relações Consulares,

\footnotetext{
${ }^{24}$ STF. Ação Cível Originária n. 298, do Distrito Federal. Tribunal Pleno. Relator Min. Soares Munoz. Julgamento de 14 de abril de 1982. DJ, 17.12.1982. p. 13201. Uma crítica da decisão está em MAGALHÃES, José Carlos de. O Supremo Tribunal Federal e o Direito Internacional: uma análise crítica. Porto Alegre: Livraria do Advogado, 2000. p. 150-172.
} 
disposição que expressamente exclui das imunidades pessoais a proteção em ações por acidentes de trânsito $^{25}$ :

Imunidade de jurisdição. Ação de reparação de danos, por acidente de trânsito, movida contra o Consulado-Geral da Polônia e o Cônsul da Polônia. Sentença que deu pela extinção do processo, sem julgamento do mérito, reconhecendo a imunidade de jurisdição. Veículo de propriedade do consulado, mas dirigido, na ocasião do acidente, pelo cônsul. Aplicação ao caso da Convenção de Viena sobre Relações Consulares, de 1963 (art. 43, parágrafo 2, letra "b") e não da Convenção de Viena sobre Relações Diplomáticas, de 1961. Imunidade de jurisdição, que é de acolher-se, em relação à Republica Popular da Polônia, de que o Consulado-Geral é uma repartição. No que respeita ao cônsul, mesmo admitindo que o veículo automotor, envolvido no acidente de trânsito, pertença ao Consulado-Geral da Polônia, certo era o condutor do automóvel e não goza, no caso, de imunidade de jurisdição (Convenção de Viena sobre Relações Consulares de 1963, art. 43, parágrafo 2, letra “b”), podendo, em consequencia, a ação movida, também, contra ele, prosseguir, para final apuração de sua responsabilidade, ou não, no acidente, com as consequencias de direito. Provimento, em parte, à apelação dos autores, para determinar prossiga a ação contra o cônsul, mantida a extinção do processo sem julgamento do mérito, relativamente a Republica Popular da Polônia (Consulado-Geral da Polônia em Curitiba). ${ }^{26}$

Decisões favoráveis aos Estados estrangeiros também são encontradas em situações de impedimento de ingresso no país. São conhecidos os constrangimentos e prejuízos sofridos pelos indivíduos a quem o acesso ao país estrangeiro é negado. Alguns deles intentaram ações no Brasil objetivando receber indenização por perdas e danos. São exemplos os seguintes casos do STJ:

\footnotetext{
${ }^{25}$ BRASIL. Decreto $n^{\circ}$ 61.078, de 26 de julho de 1967. Promulga a Convenção de Viena sobre Relações Consulares. "ARTIGO $43^{\circ}$. Imunidade de Jurisdição. 1. Os funcionários consulares e os empregados consulares não estão sujeitos à Jurisdição das autoridades judiciárias e administrativas do Estado receptor pelos atos realizados no exercício das funções consulares. 2. As disposições do parágrafo 1 do presente artigo não se aplicarão entretanto no caso de ação civil: a) que resulte de contrato que o funcionário ou empregado consular não tiver realizado implícita ou explícitamente como agente do Estado que envia; ou b) que seja proposta por terceiro como consequência de danos causados por acidente de veículo, navio ou aeronave, ocorrido no Estado receptor."

${ }^{26}$ STF. ACi 9701, Relator Min. Néri da Silveira, Tribunal Pleno, julgado em 22/10/1987, DJ 04-12-1987. p. 27639.
} 
RFD- Revista da Faculdade de Direito da UERJ, v.1, n. 19, jun./dez 2011.

A competência é da jurisprudência americana quando se trata de impedimento de ingresso no País (mesmo em trânsito) por autoridades alfandegárias. ${ }^{27}$

Logo, a prevalência dos direitos humanos e a existência de convênio de cooperação jurídica são irrelevantes na espécie, ante a limitação da própria soberania. Ademais, a imunidade relativa também abrange todos os atos jus imperii, como no caso em apreço, em que se tratam de atividades alfandegárias, típicas de poder de império. ${ }^{28}$

Em caso curioso, no qual vidente brasileiro reclama recompensa por ter avisado os Estados Unidos da América sobre o paradeiro de Saddam Hussein, decidiu também o STJ pela imunidade, embora no dispositivo o relator tenha determinado a citação do réu para que se manifestasse sobre eventual renúncia ao seu privilégio:

In casu, seja com fulcro na distinção entre atos de império e gestão, seja com lastro na comparação das praxes enumeradas em leis internas de diversas Nações como excludentes do privilégio da imunidade, inviável considerar-se o litígio, disponente sobre o recebimento, por cidadão brasileiro, de recompensa prometida por Estado estrangeiro (EUA) enquanto participante de conflito bélico, como afeto à jurisdição nacional. Em outros termos, na hipótese, tal manifestação unilateral de vontade não evidenciou caráter meramente comercial ou expressou relação rotineira entre o Estado promitente e os cidadãos brasileiros, consubstanciando, ao revés, expressão de soberania estatal, revestindo-se de oficialidade, sendo motivada, de forma atípica, pela deflagração de guerra entre o Estado ofertante (EUA) e Nação diversa (Iraque), e conseqüente persecução, por aquele, de desfecho vitorioso; por outro lado, não se inclui a promessa de recompensa, despida de índole negocial, entre as exceções habitualmente aceitas pelos costumes internacionais à regra da imunidade de jurisdição, quais sejam, ações imobiliárias e sucessórias, lides comerciais e marítimas, trabalhistas ou concernentes à responsabilidade civil

\footnotetext{
${ }^{27}$ STJ. AC n. 13-O-RS. Relator Min. Cesar Asfor Rocha. 17.11.1993.

${ }^{28}$ STJ. RO 19 / BA. 2001/0097788-3. Relator Ministro Cesar Asfor Rocha. Quarta Turma. Julgado em $2108 / 2003$.
} 
extracontratual, pelo que de rigor a incidência da imunidade à jurisdição brasileira. $^{29}$

Sem embargo da jurisprudência citada neste tópico, nota-se existirem decisões contrárias, que afastam a imunidade em incidentes geradores de responsabilidade civil do Estado estrangeiro. Em atropelamento por carro da missão, por exemplo, foi a imunidade afastada ${ }^{30}$.

\subsection{Atos comerciais}

Embora não abundem na jurisprudência brasileira casos de relações puramente comerciais entre Estados estrangeiros e particulares, encontra-se ao menos um interessante precedente, favorável à tese da separação entre atos de império e de gestão, na qual, obviamente, os atos de comércio não estão abrangidos pela imunidade, por estarem situados no âmbito dos atos de gestão:

Crédito correspondente ao fornecimento de materiais (vidros) para a construção da Chancelaria daquele país [República da Tchecoeslováquia] em Brasília. Assunto marcadamente rotineiro e de natureza comercial, que não isenta a recorrente de ser demandada, quanto ao ponto, perante a Justiça brasileira. ${ }^{31}$

Noutro acórdão do mesmo Tribunal, os atos de gestão são novamente a categoria utilizada para afastar a imunidade em processo versando sobre indenizações por descumprimento contratual:

2. Hodiernamente não se há de falar mais em imunidade absoluta de jurisdição, vez que se admite seja a mesma excepcionada nas hipóteses em que o objeto litigioso tenha como fundo relações de natureza meramente trabalhista, comercial ou civil, como ocorre na hipótese dos autos, onde o que pretende o

\footnotetext{
${ }^{29}$ STJ. RO 39/MG. 2004/0088522-2. Relator Ministro Jorge Scartezzini. Quarta Turma. Julgamento de 06/10/2005. DJ 06/03/2006. p. 387.

30 STJ. AG 36493-2/DF. Rel. Min. Antonio de Pádua Ribeiro. Segunda Turma. Julgamento de 15.08.1994. É interessante observar que neste caso o Reino Unido contestou a ação nas preliminares e no mérito.

${ }^{31}$ STJ. Ag 757 / DF. 1989/0010770-4. Ministro Sálvio de Figueiredo Teixeira. Quarta Turma.21/08/1990. DJ 01.10.1990 p. 10448.
} 
RFD- Revista da Faculdade de Direito da UERJ, v.1, n. 19, jun./dez 2011.

autor da demanda é obter reparação civil pelo suposto descumprimento de contrato verbal celebrado com o demandado para a elaboração de projeto para realização de exposição que se realizaria no Rio de Janeiro, sob a denominação de "EXPO MÉXICO - SÉCULO XXI". ${ }^{32}$

Como se observa, neste tocante a jurisprudência brasileira possui posição pacífica, equiparando os contratos comerciais a atos de gestão e submetendo-os à jurisdição nacional.

\subsection{Imunidade em matéria tributária}

A jurisprudência em matéria tributária é de todas, provavelmente a mais controversa. A explicação para essa dificuldade talvez esteja na falta de um fundamento legal para afastar a cobrança de impostos e taxas. Por ser um campo estritamente regulado pelo princípio da legalidade, tanto no campo da exigência como da nãoexigência dos tributos, o Direito Tributário lida com mais dificuldade com normas costumeiras internacionais que restringem normas internas.

No Rio de Janeiro, por exemplo, antiga sede da capital nacional, há vários imóveis de Estados estrangeiros, nos quais não estão instaladas as embaixadas respectivas, eis que estas se transferiram para Brasília. Por conseguinte, a Fazenda Municipal não encontra fundamento legal para afastar a cobrança do IPTU e taxas municipais, autuando com frequência os titulares dos imóveis. Essa ação teve resultados distintos.

Assim, houve decisão em que se reconheceu a imunidade, mas enunciando-a como relativa, determinou-se a citação. ${ }^{33}$ Noutra, em litígio contra a Argentina, o Superior Tribunal de Justiça sustentou que os débitos tributários poderiam ser contraídos por qualquer pessoa, não sendo ato específico de ato soberano. Por não recair no jus imperii, pode o autor promover a ação. ${ }^{34}$

Em caso ainda mais emblemático, relativo ao Consulado do Japão em Belém,decidiu o mesmo Tribunal:

\footnotetext{
${ }^{32}$ STJ. RO 26/RJ, Rel. Ministro Vasco Della Giustina, Terceira Turma, julgado em 20/05/2010, DJe $07 / 06 / 2010$.

${ }^{33}$ STJ. Recurso Ordinário $n^{\circ} 41-R J$. 2004/0110711-9. Relatora Ministra Eliana Calmon.

${ }^{34}$ STJ. RO 7 / RJ ; Recurso Ordinario. 1998/0001667-8. Relator Min. Francisco Peçanha Martins.Segunda Turma 01/06/1999. DJ 06.12.1999. p. 73.
} 
O Estado pratica ato "jure gestiones" quando adquire bens imóveis ou móveis.

O Egrégio Supremo Tribunal Federal, mudando de entendimento, passou a sustentar a imunidade relativa. Também o Colendo Superior Tribunal de Justiça afasta a imunidade absoluta, adotando a imunidade relativa do Estado Estrangeiro. Não se pode alegar imunidade absoluta de soberania para não pagar impostos e taxas cobrados em decorrência de serviços específicos prestados ao Estado Estrangeiro. ${ }^{35}$

Por outro lado, com apoio em fundamento nas Convenções de Viena sobre Relações Diplomáticas e Consulares, - as quais não tratam da imunidade de jurisdição do Estado estrangeiro, diga-se de passagem -, o STJ já reconheceu a imunidade em litígios contra Itália e Áustria ${ }^{36}$ :

As questões de direito público referentes à cobrança de débitos tributários estão abrangidas pela regra de imunidade de jurisdição de que goza o Estado Estrangeiro. Aplica-se, na hipótese vertente, as Convenções de Viena, de 1961 e 1963. Precedentes do Supremo Tribunal Federal.

Com o mesmo fundamento, o STF seguiu esse posicionamento. ${ }^{37} \mathrm{~A}$ imunidade em matéria tributária, aliás, recebe acolhida no $\mathrm{STF}^{38}$ Decisão recente do $\mathrm{STJ}$ dá a entender que a tendência de afirmação da imunidade nesse tocante torna-se majoritária. ${ }^{39}$

\section{Balanço final}

O cotejo das disposições da Convenção com a jurisprudência brasileira mostra, antes de mais nada, uma diferença de fundamentos. O texto convencional optou por estabelecer uma regra geral e especificar-lhe as exceções, que, quando não expressas,

\footnotetext{
${ }^{35}$ STJ. RO 6 / RJ ; Recurso Ordinario 1997/0088768-5. Relator Ministro Garcia Vieira. Primeira turma Data do Julgamento 23/03/1999. Data da Publicação/Fonte DJ 10.05.1999. p. 103.

${ }^{36}$ STJ. $R O n^{o} 35$ / RJ, Relator Ministro Teori Albino Zavascki, DJ de 23/08/2004, p. 119. STJ. AgRg no RO 29 / RJ ; Agravo Regimental No Recurso Ordinário. 2003/0171075-6. Relator Ministro Francisco Falcão. Primeira Turma. 07/10/2004.

${ }^{37}$ STF. Ação Cível Originária No 633 Agravo Regimental, relatora Ministra Ellen Gracie, julgado em 11/04/2007, DJ 22/06/2007, DJe-042.

${ }^{38}$ STF. Ação Cível Originária $\mathrm{N}^{\circ} 645$ Agravo Regimental, Relator Ministro Gilmar Mendes, julgado em 11/04/2007, DJ 17/08/2007, DJe-082.

${ }^{39}$ STJ. AgRg no Recurso Ordinário $N^{o} 105$ - RJ, Relator Ministro Hamilton Carvalhido, julgado em 18 de Novembro de 2010, DJe 16/12/2010.
} 
não podem ser subentendidas e, além disso, não devem ser interpretadas restritivamente. Apóia-se a Convenção, como fizeram as leis nacionais que a inspiraram, na "técnica de expressamente enumerar quais as atividades empreendidas pelo Estado estrangeiro que não se beneficiam das imunidades de jurisdição". 40

A jurisprudência brasileira, por sua vez, orienta-se por uma linha demarcatória traçada no grande paradigma da relativização da imunidade, delineada em 1989, e constituída pela separação entre atos de gestão e atos de império. A distância entre os dois fundamentos vem à tona pela flexibilidade interpretativa da segunda, que permitiu, numa inversão lógica, determinar que tudo o que uma pessoa natural pode fazer constitui ato de gestão passível de ser sindicado perante tribunal nacional. Viu-se, assim, que se uma pessoa pode contrair débitos tributários, quando o Estado estrangeiro o faz, não pode invocar imunidade.

A respeito da divisão entre atos de império e atos de gestão, Guido Soares lecionou que

Se bem que tenha sido considerada uma distinção sem muita precisão lógica (uma vez que não se pode distinguir um ato tomando-se por critério a finalidade de deixá-lo apto ou não ao exame dos Poderes Judiciários, além de ser uma caracterização arbitrária, sem qualquer fundamentos nos elementos componentes do ato), serviu a seus propósitos de impedir a consumação de uma injustiça contra uma pessoa de boa-fé, precisamente a que mantinha relações jurídicas legítimas com o Estado. ${ }^{41}$

A demarcação baseada na diferença de atos de gestão e império conduz a resultados distintos das regras da Convenção em alguns pontos significativos. Destacase, em particular, a exceção às avenças expressas entre o Estado de acolhimento e organização internacional, permitidas pela Convenção (aplicável apenas por analogia às organizações internacionais), mas até agora ignoradas pelo TST. Destoam também da Convenção os parâmetros para determinar a incidência da imunidade em casos de responsabilidade civil. Na Convenção, enfoca-se o objeto do dano, se a integridade ou

${ }^{40}$ SOARES, Guido. Órgãos dos Estados nas relações internacionais: formas da diplomacia e imunidades. Rio de Janeiro: Forense, 2001. p. 186.

${ }^{41}$ SOARES, Guido. Curso de Direito Internacional Público. São Paulo: Atlas, 2002. p. 277. V. tb. BROWNLIE, Ian. Princípios de Direito Internacional. Trad. Maria Manuela Ferrajota et al. Lisboa: Calouste Gulbenkian, 1997. p. 354. 
vida da pessoa natural, ou o patrimônio tangível ou intangível de pessoa física ou jurídica. A jurisprudência nacional, repita-se, considera apenas a natureza do ato (se de gestão ou império). Adotada a Convenção, a Polônia não seria excluída do feito movido por vítima de acidente de trânsito. Ainda no campo das divergências, anote-se que o precedente coletado em matéria de litígios imobiliários igualmente preocuparia, não fosse ele tão antigo.

As coincidências entre as posições da jurisprudência e as normas da Convenção afloram no campo das transações comerciais e também nas questões trabalhistas, ressalva feita ao exposto em parágrafo anterior. As posições predominantes em matéria tributária, favoráveis à imunidade, igualmente são convergentes em relação à Convenção.

\section{Conclusões}

De todo o acima exposto, resulta demonstrado que a adesão à Convenção das Nações Unidas sobre Imunidade dos Estados e seus Bens traria ao Brasil maior segurança jurídica, evitando as oscilações apontadas no decorrer do trabalho. De um modo geral, as posições prevalecentes não seriam alteradas. Com efeito, se tomadas grosso modo, ignorando detalhes e casos destoantes, as decisões nacionais afastam a imunidade nas contratações de empregados domiciliados no Brasil ou brasileiros, nos casos de responsabilidade civil causados por atos de gestão e nas questões comerciais, reconhecendo-a em matéria tributária e nas obrigações de responsabilidade civil derivadas de atos de império. A Convenção traria sobre esses campos apenas ajustes e definições, evitando distorções e insegurança jurídica.

Conclui-se, pois, que a Convenção evitará ao menos parte das divergências hoje percebidas nos tribunais, permitindo a adoção de orientações mais claras em relação a essa matéria, cuja repercussão sente-se não somente nas salas dos tribunais, mas também no campo da diplomacia, com reflexos sobre a imagem do País.

\section{Referências Bibliográficas}


BROWNLIE, Ian. Princípios de Direito Internacional. Trad. Maria Manuela Ferrajota et al. Lisboa: Calouste Gulbenkian, 1997.

CANADA. Act to Provide for Immunity in Canadian Courts. International Legal Materials, v. 21, p. 798-801, 1982.

MADRUGA Filho, Antenor P.; GARCIA, Márcio. (Orgs.) A imunidade de jurisdição e o judiciário brasileiro. CEDI: Brasília, 2002. p. 202.

MAGALHÃES, José Carlos de. O Supremo Tribunal Federal e o Direito Internacional: uma análise crítica. Porto Alegre: Livraria do Advogado, 2000.

MEDEIROS, Antonio Paulo Cachapuz (org.). Pareceres dos Consultores Jurídicos do Itamaraty. Volume VI (1961-1971). Brasília: Senado Federal, 2002, p. 118.

MELLO, Rubens Ferreira de. Textos de Direito Internacional e de História Diplomática. Rio de Janeiro: Coelho Branco Fo , 1950. p. 781-797.

MINISTÉRIO DAS RELAÇÕES EXTERIORES. Nota Circular $n$. 18/95.

SALIBA, Aziz Tuffi. A imunidade absoluta de jurisdição de Estados: "sólida regra costumeira" ou mito? Revista Brasileira de Direito Público, Belo Horizonte, v. n. 8, p. 23-33, 2005.

SOARES, Guido. Curso de Direito Internacional Público. São Paulo: Atlas, 2002.

SOARES, Guido. Órgãos dos Estados nas relações internacionais: formas da diplomacia e imunidades. Rio de Janeiro: Forense, 2001.

SOARES, Guido. Órgãos dos Estados nas relações internacionais: formas da diplomacia e imunidades. Rio de Janeiro: Forense, 2001.

STF. Ação Cível Originária n. 298, do Distrito Federal. Tribunal Pleno. Relator Min. Soares Munoz. Julgamento de 14 de abril de 1982. DJ, 17.12.1982. p. 13201.

STF. ACi 9701, Relator Min. Néri da Silveira, Tribunal Pleno, julgado em 22/10/1987, DJ 04-12-1987. p. 27639.

STF. ACi 9703 / SP. Relator Min. Djaci Falcao. Tribunal Pleno. Julgamento 28/09/1988. DJ 27-10-1989. p.16391.

STF. ACO 543 AgR, Relator Min. Sepúlveda Pertence, Tribunal Pleno, julgado em 30/08/2006, DJ 24-11-2006, p. 61.

STF. Apelação Cível n. 9696. de São Paulo. Tribunal Pleno. Relator Min. Sydney Sanches. Julgamento de 31de maio de 1989. DJ, 12.10.1990. p. 11045.

STF. $R E 222368$ AgR, Relator Min. Celso de Mello, Segunda Turma, julgado em 30/04/2002, DJ 14-02-2003. p. 70. 
STF. RE 578543 / MT. Relatora Min. Ellen Gracie. Ainda não julgado. Movimentação disponível em: <www.stf.jus.br>.

STF. Ação Cível Originária $N^{\circ} 633$ Agravo Regimental, Relatora Ministra Ellen Gracie, julgado em 11/04/2007, DJ 22/06/2007, DJe-042.

STF. Ação Cível Originária No 645 Agravo Regimental, Relator Ministro Gilmar Mendes, julgado em 11/04/2007, DJ 17/08/2007, DJe-082.

STJ, Recurso Especial $N^{o}$ 436.711, Relator Ministro Humberto Gomes de Barros, julgado em 25/04/2006 DJ 22/05/2006.

STJ, Recurso Ordinário $N^{o}$ 57, Relatora Ministra Nancy Andrighi, Relator p/ acórdão Ministro Aldir Passarinho Junior, voto-vista do Ministro Sidnei Benetti, julgado em 21/08/2008, DJe 14/09/2009.

STJ, Recurso Ordinário $N^{o}$ 69, Relator Ministro João Otávio de Noronha, julgado em 10/06/2008, DJe 23/06/2008.

STJ, Recurso Ordinário $N^{o} 78$, Relator Ministro João Otávio de Noronha, julgado em 18/08/2009, DJe 08/09/2009.

STJ, Recurso Ordinário $N^{o} 1$, Relator Ministro Cláudio Santos, julgado em 08/08/1995, DJ 11/09/1995.

STJ, Recurso Ordinário $N^{\circ} 23$, Relator Aldir Passarinho Junior, julgado em 28/10/2003, DJ 19/10/2003.

STJ, Recurso Ordinário $N^{o} 39$, Relator Ministro Jorge Scartezzini, julgado em 06/10/2005, DJ 06/03/2006.

STJ, Recurso Ordinário $N^{o} 6$, Relator Ministro Garcia Vieira, julgado em 23/03/1999, DJ 10/05/1999.

STJ, Recurso Ordinário $N^{\circ} 72$, Relator João Otávio de Noronha, julgado em 18/08/2009, DJe 08/09/2009.

STJ. AC n. 13-0-RS. Relator Min. Cesar Asfor Rocha. 17.11.1993.

STJ. AG 36493-2/DF. Rel. Min. Antonio de Pádua Ribeiro. Segunda Turma. Julgamento de 15.08.1994. É interessante observar que neste caso o Reino Unido contestou a ação nas preliminares e no mérito.

STJ. Ag 757 / DF. 1989/0010770-4. Ministro Sálvio de Figueiredo Teixeira. Quarta Turma.21/08/1990. DJ 01.10.1990 p. 10448.

STJ. AgRg no RO 29 / RJ ; Agravo Regimental No Recurso Ordinário. 2003/0171075-6. Relator Ministro Francisco Falcão. Primeira Turma. 07/10/2004. 
STJ. Apelação Cível $N^{o}$ 9, Relator Ministro Dias Trindade, julgado em 30/09/1991, DJ 28/10/1991.

STJ. Apelação Cível N², Relator Ministro Barros Monteiro, julgado em 07/08/1990, DJ 03/09/1990.

STJ. Recurso Ordinário $N^{o}$ 26, Relator Ministro Vasco Della Giustina, julgado em 20/05/2010, DJe 07/06/2010.

STJ. Recurso Ordinário $N^{o} 33$, Relatora Ministra Nancy Andrighi, julgado em 02/06/2005, DJ 20/06/2005.

STJ. Recurso Ordinário $n^{o} 41-R J .2004 / 0110711-9$. Relatora Ministra Eliana Calmon.

STJ. AgRg no Recurso Ordinário $N^{\circ} 105$ - RJ, Relator Ministro Hamilton Carvalhido, julgado em 18 de Novembro de 2010, DJe 16/12/2010.

STJ. Recurso Ordinário $N^{o}$ 57, Relatora Ministra Nancy Andrighi, Relator p/ acórdão Ministro Aldir Passarinho Junior, julgado em 21/08/2008, DJe 14/09/2009.

STJ. RO 19/BA. 2001/0097788-3. Relator Ministro Cesar Asfor Rocha. Quarta Turma. Julgado em 21/08/2003.

STJ. RO 23/PA. Recurso Ordinario. 2002/0096286-5. Relator Ministro Aldir Passarinho Junior. Quarta Turma. 28/10/2003. DJ 19.12.2003 p. 464. STJ. RO 33/RJ. 2003/0235440-6. Relatora Ministra Nancy Andrighi. Terceira Turma. 02062005.

STJ. $R O$ 26/RJ, Rel. Ministro Vasco Della Giustina, Terceira Turma, julgado em 20/05/2010, DJe 07/06/2010.

STJ. RO 39 / MG. 2004/0088522-2. Relator Ministro Jorge Scartezzini. Quarta Turma. Julgamento de 06/10/2005. DJ 06/03/2006. p. 387.

STJ. RO 6 / RJ ; Recurso Ordinario 1997/0088768-5. Relator Ministro Garcia Vieira. Primeira turma Data do Julgamento 23/03/1999. Data da Publicação/Fonte DJ 10.05.1999. p. 103.

STJ. RO 7 / RJ ; Recurso Ordinario. 1998/0001667-8. Relator Min. Francisco Peçanha Martins.Segunda Turma 01/06/1999. DJ 06.12.1999. p. 73.

STJ. $R O n^{o} 35$ / RJ, Relator Ministro Teori Albino Zavascki, DJ de 23/08/2004, p. 119.

TST. $R R$ - 3386/1997-658-09-00.0. Rel. Maria Cristina Irigoyen Peduzzi. 14/08/2009.

TST. $\quad R R$ - 1663/2002-005-23-00.8. Rel. Maria de Assis Calsing, 13/05/2009.

TST. AIRR - 83140-02.2003.5.10.0008, Relator Ministro Mauricio Godinho Delgado, Data de Julgamento: 26/05/2010, 6 a Turma, Data de Publicação: 04/06/2010. 
UNITED KINGDOM. State Immunity Act. International Legal Materials, v. 17, p. 1123-1129, 1978.

UNITED NATIONS. Convention on Jurisdictional Immunities of States and Their Property. Adopted by the General Assembly of the United Nations on 2 December 2004. Official Records of the General Assembly, Fifty-ninth Session, Supplement No. 49 (A/59/49). Disponível na internet: <http://untreaty.un.org/ilc/texts/instruments/english/conventions/4_1_2004.pdf >. Acesso em 28.08.10.

UNITED STATES OF AMERICA. Foreign Immunities Act. International Legal Materials, v. 15, p. 1388-1392, 1976.

UNITED STATES. Department of State. Tate Letter. 19.05.1952. Disponível na internet: <http://www.law.berkeley.edu/faculty/ddcaron>. Acesso em 24 de setembro de 2006. 